\title{
Species- and age-dependent distribution of retinol and a-tocopherol in the Canidae family during the cold season
}

\author{
Irina Baishnikova, Tatiana Ilyina, Viktor llyukha, and \\ Konstantin Tirronen
}

Institute of Biology of the Karelian Research Centre of the Russian Academy of Sciences (IB KarRC RAS), ul. Pushkinskaya, 11, Petrozavodsk, Karelia, 185610, Russian Federation

Address correspondence and requests for materials to Irina Baishnikova, iravbai@mail.ru

Citation: Baishnikova, I., llyina, T., llyukha, V, and Tirronen, K. 2021. Speciesand age-dependent distribution of retino and a-tocopherol in the Canidae family during the cold season. Bio. Comm. 66(3): 225-235. https://doi.org/10.21638/ spbu03.2021.304

Authors' information: Irina Baishnikova, $\mathrm{PhD}$, Senior Researcher, orcid.org/00000001-5064-3731; Tatiana llyina, PhD, Senior Researcher, orcid.org/0000-0001-8708-7775; Viktor Ilyukha, Dr. of Sci. in Biology, Director of Institute, orcid.org/0000-0002-70854154; Konstantin Tirronen, PhD, Head of Laboratory, orcid.org/0000-0002-8208-5460

Manuscript Editor: Michael Firsov, Sechenov Institute of Evolutionary Physiology and Biochemistry, Russian Academy of Sciences, Saint Petersburg, Russia

Received: May 22, 2020;

Revised: April 14, 2021;

Accepted: June 11, 2021.

Copyright: (c) 2021 Baishnikova et al. This is an open-access article distributed under the terms of the License Agreement with Saint Petersburg State University, which permits to the authors unrestricted distribution, and self-archiving free of charge.

Funding: This study was carried out under state order (projects No 0218-2019-0073, 0218-2019-0080).

Ethics statement: The studies were carried out in accordance with the guidelines of FELASA (Guillen, 2012) and approved by the Local Ethic Committee of the Institute of Biology of the Karelian Research Centre of the Russian Academy of Sciences (Approval No 04).

Competing interests: The authors have declared that no competing interests exist.

\begin{abstract}
Vitamins $\mathrm{A}$ and $\mathrm{E}$ are known as nutrients involved in metabolic processes and facilitating the adaptation of animals. The metabolism of these vitamins is closely related to lipid metabolism, which has seasonal variations in animals inhabiting northern latitudes. The aim of this study was to investigate the concentrations of retinol (vitamin A) and a-tocopherol (vitamin E) in the cold season (October to February) in tissues of Canidae species that have different ecological characteristics: the blue fox (Vulpes syn. Alopex lagopus), silver fox (Vulpes vulpes), their interspecific hybrids (Vulpes $\times$ Vulpes), raccoon dog (Nyctereutes procyonoides), and grey wolf (Canis lupus). In addition, age-related differences in the levels of these vitamins were determined. Results showed the distribution of retinol and a-tocopherol in the body of the canids was similar, with larger amounts being found in the liver and kidney cortex, which play a regulatory role in the metabolism of these nutrients. The higher retinol level in the liver of wolves and interspecific hybrids of blue fox and silver fox, as compared to the retinol level in the liver of other species, might be species-specific and could also be attributed to dietary differences. The blue fox and raccoon dog both have a higher capacity for a-tocopherol accumulation in the cold season, apparently due to their ability to store substantial fat reserves. Retinol and a-tocopherol levels were generally higher in the tissues of mature animals.
\end{abstract}

Keywords: canids, cold season, ecological features, retinol, a-tocopherol

\section{Introduction}

The Canidae family comprises species inhabiting every continent (except Antarctica) and adapted to living in a wide range of climatic conditions. Various breeds and color types of the red fox (Vulpes vulpes), arctic fox (Vulpes syn. Alopex lagopus) and raccoon dog (Nyctereutes procyonoides) are reared in captivity for furs. The farm-bred silver fox is a mutant color type of the wild red fox, which has the widest geographical distribution among members of the family: from tundra to deserts. The blue fox was bred through selection within the wild blue arctic fox, which is a typical inhabitant of the Arctic and Sub-Arctic regions (Nes et al., 1988). Interspecific hybrids of the silver fox and the blue fox are produced in fur farms because of an improved structure of the fur coat (Yang et al., 2016). The raccoon dog now has a wide range on the Eurasian continent: from some Japanese islands, the Korean Peninsula and China to Finland, Sweden, Poland and other European countries. Raccoon dogs of wild and white color types are bred in captivity (Nes et al., 1988; Drygala, Werner and Zoller, 2013). Despite the long period of breeding in captivity, these species retain the basic biological features of their wild ancestors, associated with nutrition, seasonal reproduction and molting. Originally, the grey wolf (Canis lupus), which is also an object of this study, inhabited a majority of habitats from high Arctic latitudes to $15^{\circ} \mathrm{N}$ (Reimers and Bibikov, 1985). 
The present-day global distribution of the wolf reflects centuries of persecution rather than the natural range of its ecological adaptation. All these species differ significantly in morphology and physiology, thus representing interesting objects for comparative study.

Vitamins $\mathrm{A}$ and $\mathrm{E}$ are essential micronutrients that play an important role in the adaptation of organisms. They are required for the maintenance of many physiological processes, including growth, development, reproduction and immune response, and also have antioxidant properties (Brigelius-Flohe, 2009; Blomhoff and Blomhoff, 2006). Their distribution in the body of mammals has significant differences and depends on the species, ecological features, age and a number of other factors (Schweigert, Buchholz and Bonitz, 1998; Ilyina, Baishnikova, Belkin and Ruokolaynen, 2014). Vitamin $\mathrm{E}$ is a generic term for a group of lipid-soluble, chainbreaking antioxidants: $\alpha-, \beta-, \gamma$ - and $\delta$-tocopherols and the corresponding tocotrienols. Among them, a-tocopherol is the most biologically active form and is selectively retained in the body (Traber, 2013). The term vitamin A includes retinol and additional retinoid metabolites including retinyl esters, retinaldehyde and retinoic acid (Estornell et al., 2000). It has been shown that canids, as well as many other carnivorous species, have peculiarities concerning the transport and distribution of vitamin A in the body (Raila et al., 2000). Because both vitamins are fat-soluble, their metabolism must be closely related to the lipid metabolism, which has seasonal variations in animals inhabiting polar and boreal regions. Information about the contents of vitamins $\mathrm{A}$ and $\mathrm{E}$ in the body of Canidae species living in the wild is scarce. The objective of the present study was to investigate retinol and $\alpha$-tocopherol levels in the liver, kidney cortex, heart and skeletal muscle of the blue fox, silver fox, their interspecific hybrids, raccoon dog and grey wolf in the cold season. In addition, age-related differences in the levels of these vitamins were determined.

\section{Materials and methods}

\section{Sampling of animals and tissues}

The study was conducted on captive-bred juvenile (6-7 months old) and mature (1.5-3.5 years old) females of silver fox and blue fox from a fur farm located in the Republic of Karelia, Russia $\left(61^{\circ} \mathrm{N}, 34^{\circ} \mathrm{E}\right)$; juvenile (6-7 months old) male interspecific hybrids of female blue fox and male silver fox (Vulpes $\times$ Vulpes) called Blue frost fox, and juvenile (7 months old) males and females of raccoon dog of standard color type from a fur farm located in the Pskov Region, Russia $\left(57^{\circ} \mathrm{N}, 28^{\circ} \mathrm{E}\right)$. The animals were kept in outdoor cages, exposed to natural photoperiod and ambient temperature and fed on wet diets for farmed foxes and raccoon dogs, formulated using typical feed components available in Russia, and water ad libitum. The composition of the diets is shown in Table 1.

Table 1. Composition of the basal diet

\begin{tabular}{|c|c|c|}
\hline \multirow{2}{*}{ Ingredients (\%) } & Blue fox & Raccoon dog \\
\hline & Silver fox & Blue Frost fox \\
\hline $\begin{array}{l}\text { Beef offal and slaughter } \\
\text { by-products }\end{array}$ & 14.9 & 19.1 \\
\hline Poultry entrails & 20.5 & 18.1 \\
\hline Poultry carcasses & 13.9 & 11.2 \\
\hline Bone and meat meal & 2.0 & 2.9 \\
\hline Preserved blood & 2.8 & 2.3 \\
\hline Cod by-products & - & 4.3 \\
\hline Fish meal & 13.2 & 10.0 \\
\hline Precooked carbohydrates & 11.5 & 12.2 \\
\hline Vegetables & 1.2 & 0.7 \\
\hline Dried yeast & 5.9 & 6.8 \\
\hline Vitamin-mineral premix ${ }^{1}$ & 0.1 & 0.1 \\
\hline Water & 14.0 & 12.3 \\
\hline Metabolic Energy (ME) (MJ/kg) & 5.634 & 5.325 \\
\hline \multicolumn{3}{|l|}{$\%$ ME from } \\
\hline Protein & 39 & 38 \\
\hline Fat & 32 & 31 \\
\hline Carbohydrates & 29 & 31 \\
\hline
\end{tabular}

1 The vitamin and mineral premix provided the following (per $\mathrm{kg}$ of feed), IU: vit. A - 1000; mg: vit. E - 30, vit. C - 100, vit. B1 - 3.0, vit. B2 - 3.0, vit. $\mathrm{B} 6-0.4$, vit. $\mathrm{B} 12-0.01$, $\mathrm{Fe}-50, \mathrm{Mn}-2.5, \mathrm{Cu}-2$, $\mathrm{Zn}-0.3, \mathrm{l}-0.1$, Se -0.03 .

All animals used for the study were in good health and showed no signs of illness. Samples of tissues (liver (right lobe), kidney cortex, heart (apex) and skeletal muscle) were collected after pelting during the standard fur production process in November 2008-2010. Average daily maximum and minimum temperatures for Karelia and the Pskov Region were 7 and $-6^{\circ} \mathrm{C}$ and 7 and $-4^{\circ} \mathrm{C}$, respectively (https://www.gismeteo.ru/diary/3934). The samples were frozen at $-25^{\circ} \mathrm{C}$ and stored for further analysis.

In addition, biological material from wild grey wolves was sampled in Karelia during the period 20062021 (October-February): juvenile (2 females 5 and 9 months old) and mature (6 females over 2.5 years old and 2 males over 3.5 years old). Average daily maximum and minimum temperatures ranged from 15 and $-10^{\circ} \mathrm{C}$ in October to 1 and $-27^{\circ} \mathrm{C}$ in February (https://www. 
gismeteo.ru/diary/3934). All samples were collected by hunters, kept frozen at $-25^{\circ} \mathrm{C}$ from the time of sampling until analyses. The skeletal muscles of mature wolves were not available for analysis.

\section{Vitamins determination}

The research was carried out using the equipment of the Core Facility of the Karelian Research Centre of the Russian Academy of Sciences. All analyses were performed within a month after sampling of tissues. The concentrations of retinol and $\alpha$-tocopherol in tissues were determined by high performance liquid chromatography. The samples of tissues $(100 \mathrm{mg})$ were homogenized in $0.9 \mathrm{ml}$ of $0.25 \mathrm{M}$ sucrose solution ( $\mathrm{pH} 7.4$ ); then $0.25 \mathrm{ml}$ of homogenate was mixed with ethanol containing an antioxidant (butylated hydroxytoluene) to precipitate proteins. After that, $\mathrm{n}$-hexane was added. The mixture was vortexed for $5 \mathrm{~min}$ for the extraction of vitamins, centrifuged at $3000 \times g$ for $10 \mathrm{~min}$, and kept for $40 \mathrm{~min}$ at $4{ }^{\circ} \mathrm{C}$. The hexane layer was injected into the HPLC system. Chromatographic separation was carried out by microcolumn chromatography with a UV detector with $\mathrm{n}$-hexane and isopropanol as an eluent (98.5:1.5). The eluate was monitored at $292 \mathrm{~nm}$ for $\alpha$-tocopherol and at $324 \mathrm{~nm}$ for retinol, and the vitamins were identified by retention time compared with pure standards (Sigma-Aldrich). Quantification was performed using UniChrom software by the external standard method. All samples were analyzed in triplicate and the mean value was used.

\section{Statistical analyses}

Preliminary tests revealed no differences between sexes in juvenile raccoon dogs, therefore data for males and females were pooled in all subsequent analyses. All the collected and calculated numerical data were converted to SI units and processed statistically as mean \pm standard error of the mean. Statistical analysis was performed by one-way analysis of variance (ANOVA) to determine significant differences between ages. In addition, we used discriminant analysis to identify the parameters that play the greatest role in interspecies differences. A $p$-value of $<0.05$ was considered statistically significant. The statistical tests were performed using SigmaStat 2.03 (SPSS Science Software Ltd., USA).

\section{Results}

\section{Retinol content}

The tissue distribution of retinol was similar among the Canidae species (Table 2); higher amounts were found in the kidney cortex and liver. The content of retinol was the highest in the kidney cortex in all the species investigated, with the exception of the raccoon dog. In this tissue, a substantial amount of vitamin was found in interspecific hybrids of blue fox and silver fox. In the liver, retinol content was higher in mature wolves and interspecific hybrids than in the other species. Although Blue frost foxes and raccoon dogs were fed the same diet, the hepatic content of this vitamin in raccoon dogs was lower. In contrast to Blue frost foxes and raccoon dogs, the levels of retinol in the liver of silver foxes and blue foxes were much lower, although the two species were fed a basal diet additionally enriched with vitamin A.Among these species, the level of retinol was 2-3 times higher in the blue fox. The retinol content in the heart was lower than in the liver and kidney cortex in almost all examined species. In the hearts of Blue frost foxes and the 5-month-old female wolf this retinoid was not detected. In the skeletal muscles of all species retinol was undetectable.

Retinol levels in the livers and renal cortices of mature silver foxes, blue foxes and grey wolves were higher compared to juvenile animals. The one-way ANOVA revealed a significant effect of age on the content of retinol in the liver $\left(\mathrm{F}=16.20, \mathrm{df}=1, \eta^{2}=49 \%, \mathrm{p}=0.001\right)$, kidney cortex $\left(\mathrm{F}=13.03, \mathrm{df}=1, \eta^{2}=43 \%, \mathrm{p}=0.002\right)$ and heart $\left(F=5.49, d f=1, \eta^{2}=24 \%, p=0.032\right)$ of blue foxes; in silver foxes a significant effect of age was found in the kidney cortex $\left(\mathrm{F}=11.17, \mathrm{df}=1, \eta^{2}=40 \%, \mathrm{p}=0.004\right)$.

\section{a-Tocopherol content}

The level of $\alpha$-tocopherol in Canidae species is shown in Table 3. High values were found in the kidney cortex and liver. Raccoon dogs and blue foxes both had higher vitamin E content in these tissues, whereas a low level was found in juvenile grey wolves. The content of $a$-tocopherol in the liver of farmed silver foxes was comparable to that of Blue frost foxes, while in the renal cortex the latter had a higher level of this vitamin. Hepatic vitamin E content in mature grey wolves was about 2 times lower than in mature blue foxes but higher than in silver foxes. Grey wolves had a low a-tocopherol level in the renal cortex. In the heart and skeletal muscle, the levels of vitamin E were usually lower than in the liver and kidney cortex (Table 2). Higher amounts of a-tocopherol in these tissues were found in blue foxes, while relatively low levels were revealed in grey wolves.

Mature blue foxes and grey wolves had a higher vitamin E content as compared with juvenile animals. The one-way ANOVA revealed a significant effect of age on the $\alpha$-tocopherol level in the liver $\left(\mathrm{F}=7.26, \mathrm{df}=1, \eta^{2}=\right.$ $30 \%, \mathrm{p}=0.015)$, kidney cortex $\left(\mathrm{F}=21.55, \mathrm{df}=1, \eta^{2}=\right.$ $56 \%, \mathrm{p}=0.0002)$ and heart $\left(\mathrm{F}=6.24, \mathrm{df}=1, \eta^{2}=27 \%\right.$, $\mathrm{p}=0.023)$ of blue foxes. 
Table 2. The content of retinol in tissues of Canidae species, $\mu \mathrm{g} / \mathrm{g}$ wet tissue (mean $\pm \mathrm{SEM}$, minimum - maximum)

\begin{tabular}{|c|c|c|c|c|}
\hline & Species & Liver & Kidney cortex & Heart \\
\hline \multirow{2}{*}{ Silver fox } & $\begin{array}{l}\text { farm-raised juvenile } \\
(n=10)\end{array}$ & $\begin{array}{l}0.76 \pm 0.18 \\
0.25-2.27\end{array}$ & $\begin{array}{l}105.24 \pm 7.76 \\
64.71-141.18\end{array}$ & $\begin{array}{l}0.32 \pm 0.06 \\
0.10-0.74\end{array}$ \\
\hline & $\begin{array}{l}\text { farm-raised mature } \\
(n=10)\end{array}$ & $\begin{array}{l}0.95 \pm 0.22 \\
0.39-2.59\end{array}$ & $\begin{array}{l}167.01 \pm 17.52^{*} \\
113.4-233.66\end{array}$ & $\begin{array}{l}0.25 \pm 0.05 \\
0.01-0.50\end{array}$ \\
\hline \multirow{2}{*}{ Blue fox } & $\begin{array}{l}\text { farm-raised juvenile } \\
(n=12)\end{array}$ & $\begin{array}{l}1.58 \pm 0.22 \\
0.70-3.40\end{array}$ & $\begin{array}{l}104.74 \pm 21.73 \\
19.04-266.20\end{array}$ & $\begin{array}{l}0.23 \pm 0.08 \\
0.01-0.69\end{array}$ \\
\hline & $\begin{array}{l}\text { farm-raised mature } \\
(n=7)\end{array}$ & $\begin{array}{l}3.57 \pm 0.54^{*} \\
1.80-5.40\end{array}$ & $\begin{array}{l}246.66 \pm 35.79 * \\
103.00-357.60\end{array}$ & $\begin{array}{l}4.47 \pm 2.42^{*} \\
0.01-18.60\end{array}$ \\
\hline Blue Frost fox & $\begin{array}{l}\text { farm-raised juvenile } \\
(n=5)\end{array}$ & $\begin{array}{l}49.54 \pm 15.43 \\
13.10-93.70\end{array}$ & $\begin{array}{l}527.92 \pm 53.51 \\
410.80-702.00\end{array}$ & nd \\
\hline Raccoon dog & $\begin{array}{l}\text { farm-raised juvenile } \\
(n=5)\end{array}$ & $\begin{array}{l}16.39 \pm 7.46 \\
7.65-38.65\end{array}$ & $\begin{array}{l}7.88 \pm 0.70 \\
6.70-10.58\end{array}$ & $\begin{array}{l}0.19 \pm 0.05 \\
0.01-0.28\end{array}$ \\
\hline \multirow{2}{*}{ Grey wolf } & $\begin{array}{l}\text { juvenile } \\
(n=2)\end{array}$ & $\begin{array}{l}10.27 \pm 8.57 \\
1.71-18.84\end{array}$ & $\begin{array}{l}10.40 \pm 5.98 \\
4.42-16.38\end{array}$ & 0.32 \\
\hline & $\begin{array}{l}\text { mature } \\
(n=8)\end{array}$ & $\begin{array}{l}64.31 \pm 12.30 \\
33.70-121.60\end{array}$ & $\begin{array}{l}92.34 \pm 17.22 \\
30.90-148.40\end{array}$ & $\begin{array}{l}2.53 \pm 0.53 \\
0.78-5.70\end{array}$ \\
\hline
\end{tabular}

nd - the parameter was below the detection limit

* differ significantly from juvenile animals, $p<0.05$.

Table 3. The content of $a$-tocopherol in tissues of Canidae species, $\mu \mathrm{g} / \mathrm{g}$ wet tissue (mean $\pm \mathrm{SEM}$, minimum - maximum)

\begin{tabular}{|c|c|c|c|c|c|}
\hline \multicolumn{2}{|c|}{ Species } & Liver & Kidney cortex & Heart & Skeletal muscle \\
\hline \multirow{2}{*}{ Silver fox } & $\begin{array}{l}\text { farm-raised juvenile } \\
(n=10)\end{array}$ & $\begin{array}{l}11.92 \pm 0.83 \\
7.94-14.85\end{array}$ & $\begin{array}{l}19.76 \pm 4.40 \\
5.96-40.10\end{array}$ & $\begin{array}{l}6.93 \pm 0.84 \\
2.41-11.03\end{array}$ & $\begin{array}{l}8.62 \pm 1.56 \\
3.97-20.05\end{array}$ \\
\hline & $\begin{array}{l}\text { farm-raised mature } \\
(\mathrm{n}=10)\end{array}$ & $\begin{array}{l}12.40 \pm 0.78 \\
6.75-16.04\end{array}$ & $\begin{array}{l}27.90 \pm 10.29 \\
4.01-97.20\end{array}$ & $\begin{array}{l}5.48 \pm 0.63 \\
2.98-8.02\end{array}$ & $\begin{array}{l}5.57 \pm 1.75 \\
0.01-17.21\end{array}$ \\
\hline \multirow{2}{*}{ Blue fox } & $\begin{array}{l}\text { farm-raised juvenile } \\
(n=12)\end{array}$ & $\begin{array}{l}26.95 \pm 1.82 \\
17.20-36.45\end{array}$ & $\begin{array}{l}74.09 \pm 8.92 \\
23.59-132.80\end{array}$ & $\begin{array}{l}22.93 \pm 5.67 \\
2.98-68.60\end{array}$ & $\begin{array}{l}24.30 \pm 5.57 \\
2.63-69.80\end{array}$ \\
\hline & $\begin{array}{l}\text { farm-raised mature } \\
(n=7)\end{array}$ & $\begin{array}{l}68.56 \pm 20.41 * \\
29.80-170.60\end{array}$ & $\begin{array}{l}144.63 \pm 12.77^{*} \\
109.80-189.00\end{array}$ & $\begin{array}{l}46.51 \pm 7.64^{*} \\
26.40-72.80\end{array}$ & $\begin{array}{l}39.74 \pm 7.21 \\
16.20-77.00\end{array}$ \\
\hline Blue Frost fox & $\begin{array}{l}\text { farm-raised juvenile } \\
(n=5)\end{array}$ & $\begin{array}{l}10.54 \pm 1.55 \\
7.30-15.90\end{array}$ & $\begin{array}{l}61.10 \pm 5.58 \\
44.90-77.40\end{array}$ & $\begin{array}{l}11.85 \pm 3.32 \\
2.80-18.80\end{array}$ & $\begin{array}{l}10.64 \pm 0.46 \\
9.20-11.50\end{array}$ \\
\hline Raccoon dog & $\begin{array}{l}\text { farm-raised juvenile } \\
(n=5)\end{array}$ & $\begin{array}{l}78.76 \pm 51.66 \\
23.14-233.65\end{array}$ & $\begin{array}{l}199.53 \pm 58.72 \\
98.30-373.85\end{array}$ & $\begin{array}{l}9.39 \pm 3.21 \\
2.43-21.42\end{array}$ & $\begin{array}{l}5.21 \pm 0.61 \\
3.93-7.09\end{array}$ \\
\hline \multirow{2}{*}{ Grey wolf } & $\begin{array}{l}\text { juvenile } \\
(n=2)\end{array}$ & $\begin{array}{l}5.31 \pm 2.66 \\
2.65-7.97\end{array}$ & $\begin{array}{l}1.78 \pm 1.06 \\
0.72-2.84\end{array}$ & $\begin{array}{l}2.36 \pm 0.19 \\
2.17-2.55\end{array}$ & $\begin{array}{l}2.52 \pm 0.38 \\
2.15-2.90\end{array}$ \\
\hline & $\begin{array}{l}\text { mature } \\
(n=8)\end{array}$ & $\begin{array}{l}24.84 \pm 16.92 \\
0.70-139.60\end{array}$ & $\begin{array}{l}4.53 \pm 2.23 \\
0.01-19.66\end{array}$ & $\begin{array}{l}3.51 \pm 0.91 \\
2.10-9.20\end{array}$ & $\mathrm{~nm}$ \\
\hline
\end{tabular}

$\mathrm{nm}$ - the parameter was not measured.

* differ significantly from juvenile animals, $p<0.05$.

\section{Discussion}

\section{Retinol content}

The liver plays a main role in vitamin A homeostasis. In hepatocytes, the newly absorbed retinyl esters are rapidly hydrolyzed to retinol - which binds to retinol-binding protein, a retinol transporter in blood - or are re-esterified and packed in cytoplasmic lipid droplets of hepatic stellate cells (HSC), which are one of the major body sites for vitamin A accumulation (Blomhoff and Blomhoff, 2006; Senoo et al., 2012). The vitamin A storage capac- ity of HSCs shows wide interspecies variations. It has been shown by Senoo et al. (2012) that in some arctic top predators like polar bears (Ursus maritimus) and arctic foxes, total vitamin A values (retinol and retinyl esters) in the liver are much higher $(9571$ and $5314 \mu \mathrm{g} / \mathrm{g}$ wet tissue, respectively) than in their genetically related continental top predators like brown bears (Ursus arctos) and red foxes (300 and $114 \mu \mathrm{g} / \mathrm{g}$ wet tissue, respectively). Quite high levels of total vitamin A have been found in the liver of ferrets (Mustela putorius furo, $2013 \mu \mathrm{g} / \mathrm{g}$ wet tissue) and dogs (Canis familiaris, $1376 \mu \mathrm{g} / \mathrm{g}$ wet tissue) (Ribaya-Mercado 
et al., 1992; Raila et al., 2000). In the study of Raila et al. (2000), in farm-raised silver foxes and raccoon dogs this indicator was 4 and $67 \mu \mathrm{g} / \mathrm{g}$ wet tissue, respectively. The vitamin A values in the liver of non-carnivorous animals like rats (Rattus norvegicus), pigs (Sus scrofa) and marmoset monkeys (Callithrix jacchus) are about 300-400 $\mu \mathrm{g} / \mathrm{g}$ wet tissue (Senoo et al., 2004; Mills, Penniston and Tanumihardjo, 2005; Sun, Surles and Tanumihardjo, 2008). The ratio of retinol to the total liver reserves of vitamin A in different animal species ranges from 2 to $38 \%$ (Majchrzak, Fabian and Elmadfa, 2006; Senoo et al., 2012). In the liver of carnivorous mammals such as ferrets, cats ( $F e$ lis catus) and brown bears, the retinol levels are 2, 11 and $21 \mu \mathrm{g} / \mathrm{g}$ wet tissue, respectively (Ribaya-Mercado et al., 1992; Raila, Mathews and Schweigert, 2002; Senoo et al., 2012). Higher values (84-208 $\mu \mathrm{g} / \mathrm{g}$ wet tissue) are found in the livers of rats, pigs and marmoset monkeys (Mills, Penniston and Tanumihardjo, 2005; Sun, Surles and Tanumihardjo, 2008; Czaplicki et al., 2017). The research of Senoo et al. (2012) has shown that the capability to store considerable amounts of vitamin A is mainly due not to the number of HSCs, but to the capacity of each HSC to form large lipid droplets. Dietary retinoid intake plays a regulatory role in lipid droplet formation (Blaner et al., 2009). Liver retinol concentration is dependent on the vitamin A status and reflects a balance between hepatic depots of vitamin A as retinyl esters and dynamic interorgan transfer and recycling of retinoids meeting the demand of the organism for bioactive retinoids such as retinoic acid, the carboxylic acid form of vitamin A (Gieng, Raila and Rosales, 2005).

In this study, a substantial amount of retinol in the liver was found in mature wolves, which may be due to species- and diet-related peculiarities. In the wild, wolves ingest all the major parts of their prey, including the liver and kidneys, which are rich in vitamin $\mathrm{A}$ (Stahler, Smith and Guernsey, 2006). The high hepatic retinol level in Blue frost foxes might be associated with their higher ability to utilize organic matter. Interspecific hybrids of blue fox and silver fox exceed the parental forms in vitality, growth energy and body size (Yang et al., 2016). The basis for the manifestation of heterosis in hybrids is considered to be the higher metabolic efficiency (Ginn, 2017). The silver fox and blue fox both had lower hepatic retinol levels than the Blue frost fox and raccoon dog. A comparable result for the liver of farmed silver foxes was reported by Raila et al. (2000), whereas the hepatic retinol level in mature blue foxes found in the present study was approximately 4 times higher than that reported by Rogstad et al. (2017). It should be noted that in this study silver foxes showed no signs of vitamin A deficiency in spite of relatively low hepatic retinol level. Raila et al. (2000) reported that the ratio of retinol to the total liver reserves of vitamin A in farm-raised silver foxes account for $12 \%$.
Extrahepatic tissues also have an important role in maintaining whole body retinoid dynamics, carrying out its storage, metabolism and mobilization. Retinoid recycling in plasma from all organs to and from the liver is a prominent feature of the plasma retinol kinetics (Shirakami et al., 2012). It has been demonstrated that lipid droplets containing stellate cells are present in the lungs, kidneys and intestine (Nagy et al., 1997). Kidneys are one of the most active sites for vitamin A metabolism and accumulate it in substantial amounts in canids and mustelids (Raila et al., 2000). This may be due to an important role of kidneys in the recycling of vitamin A in the body and its excretion, given the very high concentration of vitamin A in blood as retinol and predominantly retinyl esters in complex with lipoproteins in the above-mentioned animals (Schweigert, Buchholz and Bonitz, 1998).

In the present study, only the cortex of kidney was analyzed because it had been shown that in rats, mink (Neovison vison), blue foxes and silver foxes (Käkelä, Käkelä and Hyvärinen, 2003; Ilyina and Baishnikova, 2014) as well as in polar bears (Bechshøft, Jakobsen, Sonne and Dietz, 2011), the vitamin A level in the cortex of the kidneys was much higher than in the medulla. Our results demonstrated that the contents of retinol in the renal cortices of all examined species were higher than in the livers, with the exception of raccoon dogs. The biggest difference (176 times) was observed in farmed silver foxes, having the lowest hepatic retinol level, and the smallest one (1.5 times) was found in mature grey wolves, in which the retinol content in the liver was the highest. It is possible that in canids, the ratio between retinol concentrations in the liver and the kidneys depends partly on vitamin A status of the animal. It was shown that in rats with vitamin A shortage, retinol recycling through the kidneys was 5.5 times higher compared with vitamin A sufficient rats (Lewis, Green, Green and Zech, 1990). However, in dogs, the concentration of retinol and retinyl esters in the liver is much higher than in the kidneys (Raila et al., 2000; Kirkegaard et al., 2010). Thus, there is species specificity in canids with regard to the vitamin A distribution between the liver and the kidneys. In species other than canids and mustelids, the level of vitamin A in the kidneys is significantly lower and ranges from 0.2 to $1.5 \%$ of that in the liver (Senoo et al., 2004; Mills, Penniston and Tanumihardjo, 2005; Sun, Surles and Tanumihardjo, 2008).

In this study, a very high retinol level was found in the renal cortices of Blue frost foxes. This value was 67 times higher than that of raccoon dogs, which were kept on the same farm and had the same diet. Such differences may be associated with the peculiarities of vitamin A circulation in blood, reuptake of retinol in the renal proximal tubules and excretion of vitamin A with the urine in these species. As reported by Raila et 
al. (2000), the concentration of total vitamin A in blood plasma of the raccoon dog and silver fox, which is one of the parental forms of Blue frost foxes, was similar, but in the raccoon dog retinol was predominant ( $69 \%$ of total vitamin A), whereas in the silver fox, like in most carnivores, retinyl esters prevailed ( $64 \%$ of total vitamin A). On the contrary, in the urine of the raccoon dog retinyl esters were predominant ( $95.5 \%$ of total vitamin A) and in the silver fox it was retinol ( $65 \%$ of total vitamin A). It should be noted that the physiological occurrence of large quantities of retinol and retinyl esters in the urine is a peculiarity of canids (Schweigert, Raila and Haebel, 2002). Additionally, in the kidneys of the raccoon dog, the ratio of retinol in total vitamin A reserves was lower than in the silver fox (3 and 14\%, respectively). Thus, there may be differences in the activity of retinol esterifying enzymes in the kidneys of the raccoon dog and Blue frost fox, which is responsible for the significant difference in the kidney retinol level of these species observed in our study. A comparably high content of retinol ( $488 \mu \mathrm{g} / \mathrm{g}$ wet tissue), which accounted for $31 \%$ of total vitamin $\mathrm{A}$, in the kidney cortex of mink was previously reported by Käkelä, Käkelä and Hyvärinen (2003).

The heart is highly sensitive to oxidative injuries, and retinol has been established as an important antioxidant for the structural integrity of heart mitochondria (Estornell et al., 2000). In our study, mature blue foxes had a comparatively high cardiac retinol level. At the same time, it was not detected in the hearts of Blue frost foxes despite the fact that these animals had a higher level of retinol in the liver and kidney cortex. In the skeletal muscles of all examined species the contents of retinol were below the detection limit. It is known that retinoic acid is involved in metabolic function and is probably prevalent in muscle tissue (Pan and Baker, 2007; Lee et al., 2008).

It was established that adipose tissues regulate retinoid homeostasis: uptake, storage, mobilization and transport (Villaroya, Giralt and Iglesias, 1999). Also, vi$\operatorname{tamin} \mathrm{A}$ is involved in the regulation of the level and the functioning of body fat reserves: the low vitamin A status predominantly promotes fat deposition, while vitamin A-rich diets cause a reduction of adiposity that correlates with an increasing thermogenic potential in brown adipose tissue and skeletal muscle. Retinoic acid has been shown to inhibit adipose tissue weight-regulatory peptide leptin production and secretion (Bonet, Ribot and Palou, 2012). Thus, the level of vitamin A in tissues of Canidae species in the cold season might be determined, among other factors, by the level of adiposity and could be partly due to participation of retinoids in the regulation of energy homeostasis (Bonet et al., 2000).

In the present study, age-related augmentation of the retinol level in the liver and kidney cortex in silver foxes and blue foxes was found. These results agree with recent studies of sled dogs (Kirkegaard et al., 2010), polar bears (Bechshoft et al., 2016) and rats (Blomhoff, Berg and Norum, 1988). Because vitamin A is an important regulator of growth and differentiation in most cells of the body (Blomhoff and Blomhoff, 2006), there are increasing demands for this nutrient during periods of growth and maturation with the following elevation of vitamin A storage deposits in the organism.

\section{a-Tocopherol content}

The liver is an important place where vitamin $\mathrm{E}$ is taken up and the regulation of the forms and concentrations occurs. It is there that $\alpha$-tocopherol is incorporated into lipoproteins - its carriers in blood (Traber, 2013). After intestinal absorption during chylomicron lipolysis, some a-tocopherol is taken up by peripheral tissues (Traber, Ingold, Burton and Kayden, 1988) including kidneys, which have an intensive blood flow. In the present study, the concentration of a-tocopherol varied greatly in the renal cortices, probably due to the excretory function of kidneys and their role in the redistribution of tocopherol in the body. Although the raccoon dogs and blue foxes were kept in different farms and fed different diets, these species both had high amounts of a-tocopherol in the liver and kidney cortex.

In addition to its role as an antioxidant, vitamin $\mathrm{E}$ alters the cell membrane physical state (Patel, Sekharam and Block, 1991; Wang et al., 2006) and plays an important role in the adaptation of the body to low environmental temperatures (Kalabukhov, 1985; Venditti, Di Stefano and Di Meo, 2009). During evolution, members of the Canidae family developed different survival strategies and adaptations to the cold season that determine their ecological traits. Fat storage in autumn is an important adaptive mechanism to provide energy during the seasonal shortages of food and to insulate against low ambient temperatures (Prestrud, 1991). The autumnal fattening and wintertime weight loss are a natural part of circannual rhythms of animals regulated by photoperiod, temperature and food availability (Mustonen et al., 2007). It is known that adipose tissue represents a large reserve of vitamin $\mathrm{E}$ and has a slow rate of tocopherol release (Machlin and Gabriel, 1982). Thus, the high content of a-tocopherol in the blue fox and raccoon dog found in this study may be due to the profound autumnal fattening reported for these species (up to $35 \%$ of body weight) (Nes et al., 1988; Prestrud, 1991), although they utilize different wintering strategies. In the wild, the arctic fox stays active during the winter, whereas the raccoon dog is the only canid with passive wintering and winter sleep in the boreal climate (Mustonen et al., 2006, 2007), but it does not seem to enter winter sleep in fur farms, as a result of daily feeding and lack 
of nests (Asikainen et al., 2002). Both these species are well adapted to long-term wintertime fasting without any adverse effects, but raccoon dogs are able to withstand more prolonged periods of starvation - at least 11 weeks (Mustonen et al., 2007). The consumption of body fat as the main metabolic fuel during fasting is accompanied by enhanced fat oxidation (Tauson, Chwalibog and Ahlstrøm, 2002), and sufficient a-tocopherol content in the body may be an important factor protecting tissues against oxidative damage. The antioxidant function of vitamin $\mathrm{E}$ has been proven to be essential for preventing the oxidation of polyunsaturated fatty acids (PUFA) (Valk and Hornstra, 2000), which account for $17-19 \%$ of the adipose tissues in raccoon dogs (Käkelä and Hyvärinen, 1996) and for about $22 \%$ in arctic foxes (Nowicki et al., 2014).

The high a-tocopherol concentration in the liver and kidney cortex of the raccoon dog indicates its sufficient reserves and intensive redistribution in the body at the beginning of the cold season. The raccoon dog differs from other Canidae family members of approximately the same weight in having a relatively low kidney-tobody weight ratio, which becomes the lowest during the winter passivity (Tumanov, 2003). The lineage leading to the raccoon dog diverged early in the history of the extant Canidae, and classical systematics classifies the raccoon dog as a primitive canid (Łapa, Łapiński, Śliwiak and Barabasz, 2009).

In the present study, the silver fox had a lower a-tocopherol level in the liver and renal cortex than the blue fox and raccoon dog. The Blue frost foxes mostly occupied an intermediate position between the parental species with regard to the content of vitamin $\mathrm{E}$ in the tissues. The autumnal fat deposits of the red fox are less massive than those of the arctic fox and raccoon dog (up to $28.4 \%$ of body weight; Lefebvre, Crete, Huot and Patenaude, 1999). Animals in the wild have smaller fat stores as a result of fluctuations in food availability. It was established previously that the degree of fat reserves accumulation in the silver fox and arctic fox as well as in the raccoon dog correlates with the activity of the antioxidant enzyme superoxide dismutase in the tissues: the raccoon dog had the highest enzyme activity in the liver, kidneys, heart and spleen while in the silver fox it was the lowest (Ilukha, 2003). Rouvinen (1991) reported that the hepatic vitamin E concentration in the blue fox closely correlated with liver fat content. It is possible that $\alpha$-tocopherol content in the body of Canidae species might be determined partly by the level of body fat stores.

According to phylogenetic classification, the grey wolf belongs to the group of wolf-like canids (Zrzavý et al., 2018) and it is the largest canid that has a higher metabolic rate among members of the family Canidae (Careau, Morand-Ferron and Thomas, 2007) and accumulates fewer fat reserves than the other studied mem- bers of the family - about $15.5 \%$ (Tumanov, 2003) with total proportions of PUFAs at 9-13\% (Käkelä and Hyvärinen, 1996). In wolves, periods of fasting longer than 17 days have been reported to potentially result in increased protein catabolism (Kreeger, DelGiudice and Mech, 1997). In our study, mature wolves occupied an intermediate position between mature blue foxes and silver foxes in terms of the hepatic $a$-tocopherol level. At the same time, wolves differed from the other examined canids in having a lower vitamin E content in the kidney cortex than in the liver. In juvenile wolves, low a-tocopherol content in the renal cortices may be due to both the age of the animals and their diet. Danilov, Gursky and Kudaktin (1985) reported a high mortality rate (30-60\%) in wild wolf pups during the first 6 months of life, which is associated mostly with a lack of nutrition. In addition, wolf pups have a long growing period and achieve the body size of adult animals by the end of the first year of life, whereas the weight of the kidneys in wolves increases up to 2 years of age. It should be noted that raccoon dog, arctic fox and red fox pups reach the body size and proportions of adult animals already at the age of 6-7 months (Tumanov, 2003).

The content of a-tocopherol was mostly lower in the muscular tissues than in the liver and kidney cortex of Canidae species. Vitamin E influences the activity of various enzymes participating in cellular metabolic processes and gene expression of proteins (Brigelius-Flohe, 2009) and is capable of regulating the mitochondrial production of reactive oxygen species by maintaining mitochondrial integrity and stability (Chow, 2001). Thus, this nutrient plays an important role in the homeostasis of contracting myocytes. In the present study, the relatively low content of $a$-tocopherol was revealed in wolves. Because food intake is essential for active wild mammals, especially in the cold season, they spend a lot of time and energy in hunting. The high locomotor activity of wild animals may induce an increased utilization of vitamin $\mathrm{E}$ in metabolic processes.

In other species, the level of vitamin $\mathrm{E}$ varies widely and is associated with their taxonomy and ecological peculiarities (Ilyina, Baishnikova, Belkin and Ruokolaynen, 2014). In the liver and kidneys of Greenland sled dogs the contents of $\alpha$-tocopherol are 34.8 and $54.5 \mu \mathrm{g} / \mathrm{g}$ wet tissue, respectively (Kirkegaard et al., 2010), in the renal cortices of polar bears this value ranges from 31 to $65 \mu \mathrm{g} / \mathrm{g}$ wet tissue (Bechshøft et al., 2016). Non-carnivorous animals generally have a lower content of vitamin E. Jurczuk, Brzyska and Moniuszko-Jakoniuk (2007) reported the a-tocopherol levels in the liver and kidneys of rats were about 20 and $16 \mu \mathrm{g} / \mathrm{g}$ wet tissue, respectively. In the liver of rabbits and pigs this value is about $4-5 \mu \mathrm{g} / \mathrm{g}$ wet tissue; in the skeletal muscle of pigs - about $3 \mu \mathrm{g} / \mathrm{g}$ wet tissue (Olivares, Rey, Daza and Lopez-Bote, 2009; Strychalski, Gugołek, Brym and Antoszkiewicz, 2019). 


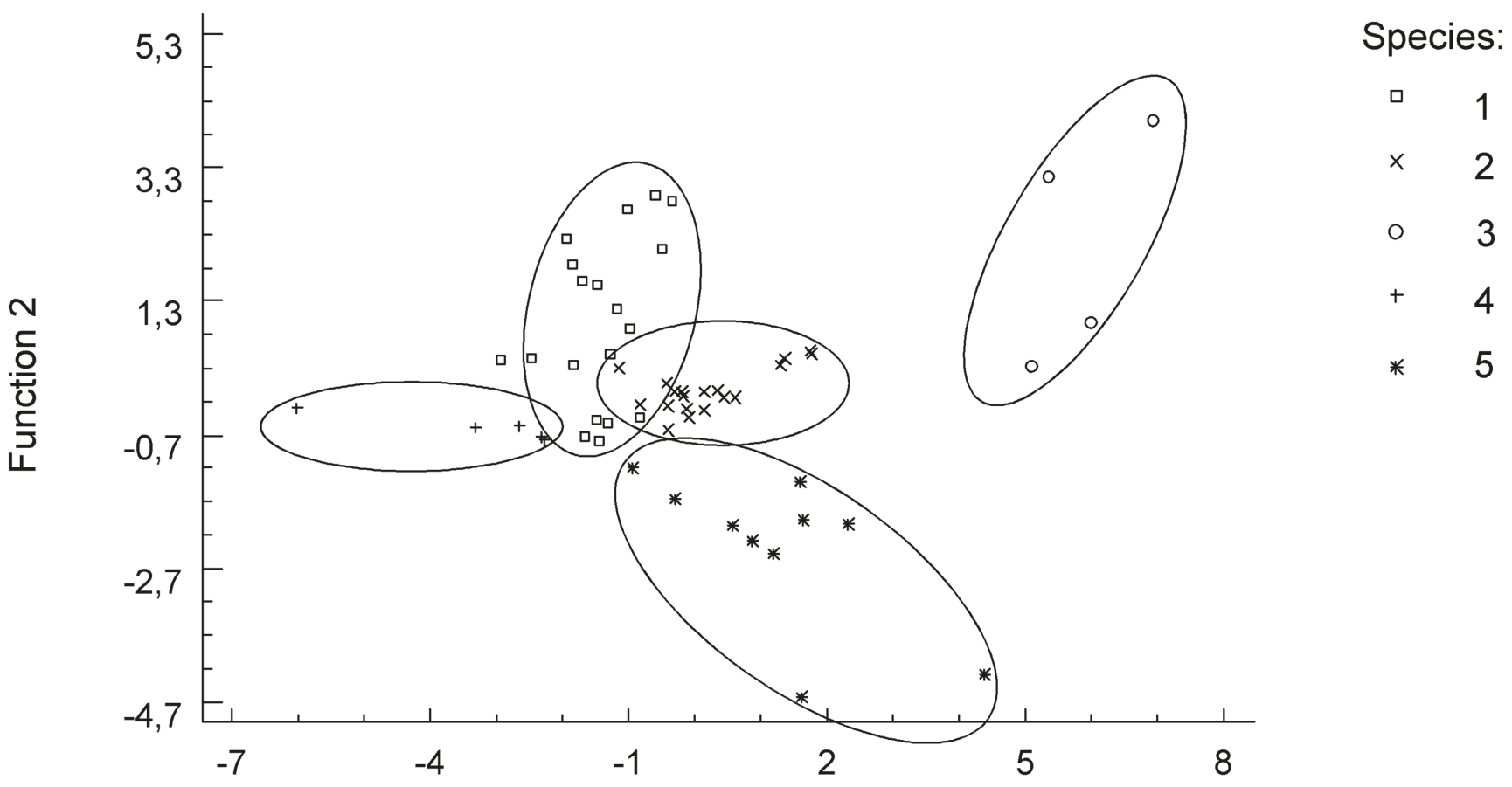

\section{Function 1}

Fig. Results of the discriminant analysis of retinol and a-tocopherol levels in the tissues of Canidae species.

1 - Blue fox, 2 - Silver fox, 3 - Blue Frost fox, 4-Raccoon dog, 5- Grey wolf.

We found that $\alpha$-tocopherol content in the examined tissues increased with age in blue foxes. Bechshoft et al. (2016) also reported that vitamin E levels in the kidney cortex and blood were higher in adult polar bears than in subadults. Unlike vitamin A, $\alpha$-tocopherol does not accumulate in excess amounts in tissues of the body (Traber, 2013) and its higher content in adult animals may be due to age-related changes in lipid metabolism (Winklhofer-Roob, van't Hof and Shmerling, 1997).

Discriminant analysis of the parameters distinctly separated the species investigated (Figure). Each species occupies its own space in the plot of discriminant functions. There is only a small overlap for blue foxes and silver foxes, possibly due to the animals being kept under identical conditions as well as the phylogenetic proximity of these species (Zrzavý et al., 2018). At the same time, raccoon dogs and interspecific hybrids of blue fox and silver fox occupy different areas in the diagram, although they were kept in the same farm. The levels of retinol and $\alpha$-tocopherol in the liver (RL, TL), kidney cortex $(\mathrm{RK}, \mathrm{TK})$ and heart $(\mathrm{RH}, \mathrm{TH})$ are the main variables that discriminated the species. Function 1 explains $59.06 \%$ of the variance (Wilks' lambda $=0.023, \mathrm{p}=$ 0.000 ) and has the following form:

$$
\begin{aligned}
& 0.502 \mathrm{RL}+0.982 \mathrm{RK}+0.061 \mathrm{RH}- \\
& -0.255 \mathrm{TL}-0.579 \mathrm{TK}-0.352 \mathrm{TH} .
\end{aligned}
$$

Function 2 explains $23.77 \%$ of the variance (Wilks' lambda $=0.127, \mathrm{p}=0.000)$ and has the following form:

$$
\begin{aligned}
& -0.565 \mathrm{RL}+0.559 \mathrm{RK}-0.156 \mathrm{RH}- \\
& -0.001 \mathrm{TL}+0.248 \mathrm{TK}+0.275 \mathrm{TH} .
\end{aligned}
$$

\section{Conclusion}

The food resources available to the red fox and arctic fox in the wild are small mammals, birds, eggs, as well as carrion from the marine ecosystem for the arctic fox. The prevalent items in the raccoon dog diet are invertebrates, carrion, amphibians, plants, and less frequently mammals, birds and fish (Rouvinen, 1991; Asikainen et al., 2002; Audet, Robbins and Larivière, 2002; Drygala et al., 2013). In the course of domestication, farmed animals have become adapted to a wider variety of foods. However, it was established (Ahlstrom, Fuglei and Mydland, 2003; Gugołek, Strychalski, Konstantynowicz and Zwoliñski, 2014) that there are no significant differences in nutrient digestibility between farmed and wild foxes and raccoon dogs, except for the higher digestibility values for carbohydrates in farm-raised blue foxes. Thus, it can be assumed that the levels of retinol and a-tocopherol in farmed animals reported in the present study reflect the capability of these species to accumulate these vitamins. 
The present investigation showed that members of the Canidae family had similar distributions of retinol and $a$-tocopherol in the body, higher levels being found in the liver and kidneys, which have a regulatory role in the metabolism of these nutrients. The blue fox and raccoon dog both have a higher capacity for a-tocopherol accumulation, probably due to profound autumnal fattening of these species. The retinol level was higher in wolves and interspecific hybrids of blue fox and silver fox, which may be species-specific or could also be attributed to diet-related differences. The concentrations of vitamins A and E were generally higher in tissues of mature animals. Canidae species demonstrated a wide range of tissue retinol and a-tocopherol accumulation patterns, which may be defined by the metabolism and function of these nutrients in the cold season. The level of vitamins in canids living in the wild can be evaluated as an indicator of their nutritional status. Future studies are needed to investigate vitamins $\mathrm{A}$ and $\mathrm{E}$ contents and distribution in canids in other seasons.

\section{Acknowledgements}

The authors thank the staff at the fur farms for providing animals and for help in the research.

\section{References}

Ahlstrom, O., Fuglei, E., and Mydland, L. T. 2003. Comparative nutrient digestibility of arctic foxes (Alopex lagopus) on Svalbard and farm-raised blue foxes (Alopex lagopus). Comparative Biochemistry and Physiology Part A: Molecular \& Integrative Physiology 134(1):63-68. https://doi. org/10.1016/S1095-6433(02)00184-8

Asikainen, J., Mustonen, A. M., Nieminen, P., Pasanen, S., Araja-Matilainen, H., and Hyvärinen, H. 2002. Reproduction of the raccoon dog (Nyctereutes procyonoides) after feeding or food deprivation in winter. Journal of Animal Physiology and Animal Nutrition 86:367-375. https:// doi/10.1046/j.1439-0396.2002.00389.x

Audet, A. M., Robbins, C. B., and Larivière, S. 2002. Alopex lagopus. Mammalian Species 713:1-10. https://doi. org/10.1644/1545-1410(2002)713<0001:AL>2.0.CO;2

Bechshøft, T. Ø., Jakobsen, J., Sonne, C., and Dietz, R. 2011. Distribution of vitamins A (retinol) and $\mathrm{E}$ (a-tocopherol) in polar bear kidney: implications for biomarker studies. Science of the Total Environment 409:3508-3511. https:// doi.org/10.1016/j.scitotenv.2011.05.036

Bechshøft, T. Ø., Sonne, C., Jakobsen, J., Rigét, F. F., Born, E. W., Letcher, R. J., Jenssen, B. M., and Dietz, R. 2016. Vitamins $A$ and $E$ in liver, kidney, and whole blood of East Greenland polar bears sampled 1994-2008: reference values and temporal trends. Polar Biology 39:743-754. https://doi.org/10.1007/s00300-015-1830-9

Blaner, W.S., O'Byrne, S. M., Wongsiriroj, N., Kluwe, J., D'Ambrosio, D. M., Jiang, H., Schwabe, R. F., Hillman, E. M., Piantedosi, R., and Libien, J. 2009. Hepatic stellate cell lipid droplets: a specialized lipid droplet for retinoid storage. Biochimica et Biophysica Acta 1791(6):467-473. https://doi.org/10.1016/j.bbalip.2008.11.001

Blomhoff, R., Berg, T., and Norum, K. R. 1988. Distribution of retinol in rat liver cells: effect of age, sex and nutritional status. British Journal of Nutrition 60:233-239. https:// doi.org/10.1079/BJN19880095

Blomhoff, R. and Blomhoff, H. K. 2006. Overview of retinoid metabolism and function. Journal of Neurobiology 66:606-630. https://doi.org/10.1002/neu.20242

Bonet, M. L., Oliver, J., Picó, C., Felipe, F., Ribot, J., Cinti, S., and Palou, A. 2000. Opposite effects of vitamin A deficient diet-feeding and retinoic acid treatment on brown adipose tissue UCP1, UCP2 and leptin expression. Journal of Endocrinology 166:511-517. https://doi.org/10.1677/ joe.0.1660511

Bonet, M. L., Ribot, J., and Palou, A. 2012. Lipid metabolism in mammalian tissues and its control by retinoic acid. Biochimica et Biophysica Acta 1821:177-189. https://doi. org/10.1016/j.bbalip.2011.06.001

Brigelius-Flohe, R. 2009. Vitamin E: The shrew waiting to be tamed. Free Radical Biology \& Medicine 46:543-554. https://doi.org/10.1016/j.freeradbiomed.2008.12.007

Careau, V., Morand-Ferron, J., and Thomas, D. 2007. Basal metabolic rate of Canidae from hot deserts to cold Arctic climates. Journal of Mammalogy 88:394-400. https://doi. org/10.1644/06-MAMM-A-111R1.1

Chow, C. K. 2001. Vitamin E regulation of mitochondrial superoxide generation. Biological Signals and Receptors 10:112-124. https://doi.org/10.1159/000046879

Czaplicki, S., Ogrodowska, D., Zadernowski, R., and Konopka, I. 2017. Effect of sea-buckthorn (Hippophaë rhamnoides L.) pulp oil consumption on fatty acids and vitamin A and $\mathrm{E}$ accumulation in adipose tissue and liver of rats. Plant Foods for Human Nutrition 72(2):198-204. https:// doi.org/10.1007/s11130-017-0610-9

Danilov, P. I., Gursky, I. G., and Kudaktin, A. N. 1985. Reproduction. In Bibikov, D. I. (ed), The Wolf. Hystory, systematics, morphology, ecology. pp. 378-389. Nauka Publ., Moscow. (In Russian)

Drygala, F., Werner, U., and Zoller, H. 2013. Diet composition of the invasive raccoon dog (Nyctereutes procyonoides) and the native red fox (Vulpes vulpes) in north-east Germany. Hystrix, the Italian Journal of Mammalogy 24(2):190-194. https://doi.org/10.4404/hystrix-24.2-8867

Estornell, E., Tormo, J. R., Marín, P., Renau-Piqueras, J., Timoneda, J., and Barber, T. 2000. Effects of vitamin A deficiency on mitochondrial function in rat liver and heart. British Journal of Nutrition 84:927-934. https://doi. org/10.1017/S0007114500002567

Gieng, S. H., Raila, J., and Rosales F.J. 2005. Accumulation of retinol in the liver after prolonged hyporetinolemia in the vitamin A-sufficient rat. Journal of Lipid Research 46(4):641-649. https://doi.org/10.1194/jlr.M400415JLR200

Ginn, B. R. 2017. The thermodynamics of protein aggregation reactions may underpin the enhanced metabolic efficiency associated with heterosis, some balancing selection, and the evolution of ploidy levels. Progress in Biophysics and Molecular Biology 126:1-21. https://doi. org/10.1016/j.pbiomolbio.2017.01.005

Gugołek, A., Strychalski, J., Konstantynowicz, M., and Zwoliñski, C. 2014. Comparative analysis of nutrient digestibility and nitrogen retention in wild and farmed canids. Annals of Animals Science 14:307-314. https://doi.org/10.2478/ aoas-2014-0002

Guillen, J. 2012. FELASA guidelines and recommendations. The Journal of the American Association for Laboratory Animal Science 51(3):311-321.

Ilukha, V. A. 2003. Superoxide dismutase and catalase in organs of three Canidae species. Scientifur 26:101-104.

Ilyina, T., Baishnikova, I., Belkin, V., and Ruokolaynen, T. 2014. Vitamins $A$ and $E$ in physiological adaptation of mam- 
mals with different ecogenesis. Acta Biologica Universitatis Daugavpiliensis 14:45-50.

Ilyina, T. N. and Baishnikova, I. V. 2014. Vitamins A and E content in the cortical and medullary kidney layers of mammals. Transactions of Karelian Research Centre of Russian Academy of Science. Experimental biology 5:218-221.

Jurczuk, M., Brzyska, M. M., and Moniuszko-Jakoniuk, J. 2007. Hepatic and renal concentrations of vitamins $E$ and $C$ in lead- and ethanol-exposed rats. An assessment of their involvement in the mechanisms of peroxidative damage. Food and Chemical Toxicology 45(8):1478-1486. https://doi.org/10.1016/j.fct.2007.02.007

Käkelä, R. and Hyvärinen, H. 1996. Site-specific fatty acid composition in adipose tissues of several northern aquatic and terrestrial mammals. Comparative Biochemistry and Physiology Part B: Biochemistry and Molecular Biology 115:501-514. https://doi.org/10.1016/S03050491(96)00150-2

Käkelä A., Käkelä R., and Hyvärinen H. 2003. Importance of the kidneys in metabolism of vitamins $A 1$ and $A 2$ and their fatty acyl esters in mink feeding on fish-based diets and exposed to Aroclor 1242. Toxicology and Applied Pharmacology 187(2):118-127. https://doi.org/10.1016/ s0041-008x(02)00067-4

Kalabukhov, N. I. 1985. Dormancy in mammals. 260 pp. Nauka Publ., Moscow. (In Russian)

Kirkegaard, M., Sonne, C., Dietz, R., Jenssen, B. M., and Letcher, R.J. 2010. Organohalogens in a whale blubber supplemented diet affects hepatic retinol and renal tocopherol concentrations in Greenland sled dogs (Canis familiaris). Journal of Toxicology and Environmental Health Part A 73:773-786. https://doi. org/10.1080/15287391003689192

Kreeger, T.J., DelGiudice, G. D., and Mech, L. D. 1997. Effects of fasting and refeeding on body composition of captive gray wolves (Canis lupus). Canadian Journal of Zoology 75:1549-1552. https://doi.org/10.1139/z97-781

Łapa, P., Łapiński, S., Śliwiak, W., and Barabasz, B. 2009. Genetic distances between the raccoon dog (Nyctereutes procyonoides) and some other Canidae spesies. Vavilov Journal of Genetics and Breeding 13:647-654.

Lee, Y. M., Lee, J. O., Jung, J.-H., Kim, J. H., Park, S.-H., Park, J. M., Kim, E.-K., Suh, P.-G., and Kim, H. S. 2008. Retinoic acid leads to cytoskeletal rearrangement through AMPKRac1 and stimulates glucose uptake through AMPKp38 MAPK in skeletal muscle cells. The Journal of Biological Chemistry 283:33969-33974. https://doi.org/10.1074/ jbc.M804469200

Lefebvre, C., Crete, M., Huot, J., and Patenaude, R. 1999. Prediction of body composition of live and post-mortem red foxes. Journal of Wildlife Diseases 35:161-170. https://doi. org/10.7589/0090-3558-35.2.161

Lewis, K. C., Green, M. H., Green, J. B., and Zech, L. A. 1990. Retinol metabolism in rats with low vitamin A status: a compartmental model. Journal of Lipid Research 31:15351548. https://doi.org/10.1016/S0022-2275(20)42338-7

Machlin, L.J., and Gabriel, E. 1982. Kinetics of tissue a-tocopherol uptake and depletion following administration of high levels of vitamin E. Annals of the New York Academy of Sciences 393:48-60. https://doi. org/10.1111/j.1749-6632.1982.tb31231.x

Majchrzak, D., Fabian, E., and Elmadfa, I. 2006. Vitamin A content (retinol and retinyl esters) in livers of different animals. Food Chemistry 98(4):704-710. https://doi. org/10.1016/j.foodchem.2005.06.035

Mills, J.P., Penniston, K. L., and Tanumihardjo, S.A. 2005. Extra-hepatic vitamin A concentrations in captive rhesus (Macaca mulatta) and marmoset (Callithrix jacchus) monkeys fed excess vitamin A. International Journal for Vitamin and Nutritional Research 75(2):126-132. https:// doi.org/10.1024/0300-9831.74.2.126

Mustonen, A.-M., Pyykönen, T., Puukka, M., Asikainen, J., Hänninen, S., Mononen, J., and Nieminen, P. 2006. Physiological adaptations to fasting in an actively wintering Canid, the Arctic blue fox (Alopex lagopus). Journal of Experimental Zoology. Part A: Comparative Experimental Biology 305:32-46. https://doi.org/10.1002/jez.a.241

Mustonen, A.-M., Käkelä, R., Käkelä, A., Pyykönen, T., Aho, J., and Nieminen, P. 2007. Lipid metabolism in the adipose tissues of a Carnivore, the raccoon dog, during prolonged fasting. Experimental Biology and Medicine 232:58-69. https://doi.org/10.3181/00379727-207-2320058

Nagy, N.E., Holven, K. B., Roos, N., Senoo, H., Kojha, N., Norum, K. R., and Blomhoff, R. 1997. Storage of vitamin A in extrahepatic stellate cells in normal rats. Journal of Lipid Research 38:645-658. https://doi.org/10.1016/ S0022-2275(20)37232-1

Nes, N. N., Einarsson, E. J., Lohi, O., Jørgensen, G., Jarosz, S. J., and Scheelje, R. 1988. Beautiful fur animals - and their colour genetics. 271 pp. Glostrup, Denmark: Scientifur.

Nowicki, S., Przysiecki, P., Filistowicz, A., Potkański, A., Filistowicz, A., and Wójtowski, J. 2014. The effect of different fat sources in the diet on the composition of adipose tissue in arctic foxes (Alopex lagopus L.). Folia Biologica 62:127133. https://doi.org/10.3409/fb62_2.127

Olivares, A., Rey, A. I., Daza, A., and Lopez-Bote, C. J. 2009. High dietary vitamin $\mathrm{A}$ interferes with tissue a-tocopherol concentrations in fattening pigs: a study that examines administration and withdrawal times. Animal 3(9):12641270. https://doi.org/10.1017/S175173110900487X

Pan, J. and Baker, K. M. 2007. Retinoic acid and the heart. Vitamins \& Hormones 75:257-283. https://doi.org/10.1016/ S0083-6729(06)75010-5

Patel, J. M., Sekharam, M., and Block, E. R. 1991. Vitamin E distribution and modulation of the physical state and function of pulmonary endothelial cell membranes. Experimental Lung Research 17:707-723. https://doi. org/10.3109/01902149109062874

Prestrud, P. 1991. Adaptations by the arctic fox (Alopex lagopus) to the polar winter. Arctic 44:132-138. https://doi. org/10.14430/arctic1529

Raila, J., Buchholz, I., Aupperle, H., Raila, G., Schoon, H.-A., and Schweigert, F.J. 2000. The distribution of vitamin A and retinol-binding protein in the blood plasma, urine, liver and kidneys of carnivores. Veterinary Research 31:541551. https://doi.org/10.1051/vetres:2000138

Raila, J., Mathews, U., and Schweigert, F. J. 2001. Plasma transport and tissue distribution of $\beta$-carotene, vitamin $A$ and retinol-binding protein in domestic cats. Comparative Biochemistry and Physiology Part A 130(4):849-856. https://doi.org/10.1016/s1095-6433(01)00443-3

Reimers, N. F. and Bibikov, D. I. 1985. Range and its modification. In Bibikov, D. I. (ed), The Wolf. Hystory, systematics, morphology, ecology. pp. 51-63. Nauka Publ., Moscow. (In Russian)

Ribaya-Mercado, J.D., Fox, J.G., Rosenblad, W.D., BlanCo, M. C., and Russell, R. M. 1992. Beta-carotene, retinol and retinyl ester concentrations in serum and selected tissues of ferrets fed beta-carotene. The Journal of Nutrition 122:(9)1898-1903. https://doi.org/10.1093/ jn/122.9.1898

Rogstad, T.W., Sonne, C., Villanger, G. D., Ahlstøm, Ø., Fuglei, E., Muir, D. C. G., Jørgensen, E., and Jenssen, B. M. 2017. Concentrations of vitamin A, E, thyroid and testosterone hormones in blood plasma and tissues from emaciated adult male Arctic foxes (Vulpes lagopus) di- 
etary exposed to persistent organic pollutants (POPs). Environmental Research 154:284-290. https://doi. org/10.1016/j.envres.2017.01.017

Rouvinen, K. 1991. Dietary effects of omega-3 polyunsaturated fatty acids on body fat composition and health status of farm-raised blue and silver foxes. Acta Agriculturae Scandinavica 41:401-414. https://doi. org/10.1080/00015129109439923

Schweigert, F. J., Buchholz, I., and Bonitz, K. 1998. Effect of age on the levels of retinyl esters in blood, plasma, liver and kidney of dogs. International Journal for Vitamin and Nutrition Research 68:237-241.

Schweigert, F. J., Raila, J., and Haebel, S. 2002. Vitamin A excreted in the urine of canines is associated with a TammHorsfall like protein. Veterinary Research 33:299-311. https://doi.org/10.1051/vetres:2002018

Senoo, H., Wake, K., Wold, H. L., Higashi, N., Imai, K., Moskaug, J. Ø., Kojima, N., Miura, M., Sato, T., Sato, M., Roos, N., Berg, T., Norum, K. R., and Blomhoff, R. 2004. Decreased capacity for vitamin A storage in hepatic stellate cells for arctic animals. Comparative Hepatology 3(Suppl 1):S18. https://doi.org/10.1186/1476-5926-2-S1-S18

Senoo, H., Imai, K., Mezaki, Y., Miura, M., Morii, M., Fujiwara, M., and Blomhoff, R. 2012. Accumulation of vitamin A in the hepatic stellate cell of arctic top predators. The Anatomical Record 295:1660-1668. https://doi.org/10.1002/ar.22555

Shirakami, Y., Lee, S.-A., Clugston, R. D., and Blaner, W.S. 2012. Hepatic metabolism of retinoids and disease associations. Biochimica et Biophysica Acta 1821(1):124-136. https://doi.org/10.1016/j.bbalip.2011.06.023

Stahler, D. R., Smith, D. W., and Guernsey, D. S. 2006. Foraging and feeding ecology of the gray wolf (Canis lupus): lessons from Yellowstone National Park, Wyoming, USA. The Journal of Nutrition 136:1923S-1926S. https://doi. org/10.1093/jn/136.7.1923S

Strychalski, J., Gugołek, A., Brym, P., and Antoszkiewicz, Z. 2019. Effect of the $\beta$-carotene oxygenase 2 genotype on the content of carotenoids, retinol and a-tocopherol in the liver, fat and milk of rabbit does, reproduction parameters and kitten growth. Journal of Animal Physiology and Animal Nutrition 103(5):1585-1593. https://doi.org/10.1111/jpn.13130

Sun, T., Surles, R. L., and Tanumihardjo, S. A. 2008. Vitamin A concentrations in piglet extrahepatic tissues respond differently ten days after vitamin A treatment. The Journal of Nutrition 138:1101-1106. https://doi.org/10.1093/ jn/138.6.1101

Tauson, A.-H., Chwalibog, A., and Ahlstrøm, Ø. 2002. Substrate oxidation in male blue fox (Alopex lagopus) during feed- ing, fasting and realimentation. The Journal of Nutrition 132:1793-1795. https://doi.org/10.1093/jn/132.6.1793S

Traber, M. G., Ingold, K. U., Burton, G.W., and Kayden, H.J. 1988. Absorption and transport of deuterium-substituted $2 R, 4^{\prime} R, 8^{\prime} R$ alpha-tocopherol in human lipoproteins. Lipids 23:791-797. https://doi.org/10.1007/BF02536223

Traber, M. G. 2013. Mechanisms for the prevention of vitamin E excess. The Journal of Lipid Research 54:2295-2306. https://doi.org/10.1194/jlr.R032946

Tumanov, I. L. 2003. Bioligocal characteristics of carnivores mammals of Russia. 448 pp. Nauka Publ., Saint-Petersburg. (In Russian)

Valk, E. E. J. and Hornstra, G. 2000. Relationship between vitamin $E$ requirement and polyunsaturated fatty acid intake in man: a review. International Journal for Vitamin and Nutrition Research 70:31-42. https://doi.org/10.1024/03009831.70.2.31

Venditti, P., Di Stefano, L., and Di Meo, S. 2009. Vitamin E reduces cold-induced oxidative stress in rat skeletal muscle decreasing mitochondrial $\mathrm{H}_{2} \mathrm{O}_{2}$ release and tissue susceptibility to oxidants. Redox Report 14:165-175. https://doi.org/10.1179/135100009X466113

Villaroya, F., Giralt, M., and Iglesias, R. 1999. Retinoids and adipose tissues: metabolism, cell differentiation and gene expression. International Journal of Obesity 23:1-6. https://doi.org/10.1038/sj.ijo.0800799

Wang, F., Wang, T., Lai, J., Li, M., and Zou, C. 2006. Vitamin E inhibits hemolysis induced by hemin as a membrane stabilizer. Biochemical Pharmacology 71:799-805. https:// doi.org/10.1016/j.bcp.2005.12.002

Winklhofer-Roob, B. M., van't Hof, M. A., and Shmerling, D. H. 1997. Reference values for plasma concentrations of vitamin $E$ and $A$ and carotenoids in a Swiss population from infancy to adulthood, adjusted for seasonal influences. Clinical Chemistry 43:146-153. https://doi. org/10.1093/clinchem/43.1.146

Yang, T. A., Yang, Y. H., Peng, Y. H., Cong, B., Diao, Y. F., Bao, K., Hu, P. F., Song, X. C., Liu, L. L., Yang, Y. F., Xing, X. M., and Yang, F. H. 2016. Comparative studies on testicular and epididymal morphology, and serum hormone concentrations in foxes and the hybrids during the breeding season. Animal Reproduction Science 168:66-72. https:// doi.org/10.1016/j.anireprosci.2016.02.027

Zrzavý, J., Duda, P., Robovský, J., Okřinová I., and Pavelková Ričánková, V. 2018. Phylogeny of the Caninae (Carnivora): Combining morphology, behaviour, genes and fossils. Zoologica Scripta 47:373-389. https://doi. org/10.1111/zsc.12293 